\title{
3. EXPLANATORY NOTES: DEEP SEA DRILLING PROJECT LEG 72, BRAZIL BASIN-RIO GRANDE RISE ${ }^{1}$
}

\author{
William T. Coulbourn, Scripps Institution of Oceanography, University of California at San Diego, \\ La Jolla, California
}

\section{SURVEY AND DRILLING DATA}

The survey data used for specific site selections are given in each site chapter. On passage between sites, continuous observations were made of depth, magnetic field, and sub-bottom structure. We used a precision echo sounder, seismic profiles, and magnetometer to make short surveys on Glomar Challenger before dropping the beacon.

Depths were continuously recorded underway on a Gifft precision graphic recorder. The sea depth (in m) at each site was corrected (1) according to the tables of Matthews (1939) and (2) for the depth of the hull transducer $(6 \mathrm{~m})$ below sea level. In addition, any depths referred to the drilling platform have been calculated on the assumption that this level is $10 \mathrm{~m}$ above the water line.

The seismic profiling system consisted of two Bolt air guns, a Scripps-designed hydrophone array, Bolt amplifiers, two bandpass filters, and two EDO recorders, usually recording at two different filter settings.

\section{Drilling Characteristics}

Because water circulation down the hole is open, cuttings are lost onto the seabed and cannot be examined. The only available information about sedimentary stratification between cores, other than from seismic data, is from an examination of the behavior of the drill string as observed on the drill platform. The harder the layer being drilled, the slower and more difficult it is to penetrate. A number of other variable factors, however, determine the rate of penetration, so it is not possible to relate this directly to the hardness of the layers. Among these, the parameters of bit weight and revolutions per minute are recorded on the drilling recorder.

\section{Drilling Deformation}

When the cores are split, many show signs of the sediment having been disturbed since its deposition. Such signs include the concave-downward appearance of originally plane bands, the haphazard mixing of lumps of different lithologies, and the near-fluid state of some sediments recovered from tens or hundreds of meters below the seabed. It seems reasonable to suppose that this deformation came about during or after the cutting

\footnotetext{
${ }^{1}$ Barker, P. F., Carlson, R. L., Johnson, D. A., et al., Init. Repts. DSDP, 72: Washington (U.S. Govt. Printing Office).
}

of the core. Three different stages during which the core may suffer stresses sufficient to alter its physical characteristics are cutting, retrieval (with accompanying changes in pressure and temperature), and core handling aboard ship.

\section{SHIPBOARD SCIENTIFIC PROCEDURES}

\section{Numbering of Sites, Holes, Cores, Sections, and Samples}

DSDP drill sites are numbered consecutively from the first site drilled by Glomar Challenger in 1968. Site numbers are slightly different from hole numbers. A site number refers to one or more holes drilled while the ship was positioned over one acoustic beacon. These holes could be within a radius as great as $900 \mathrm{~m}$ from the beacon. Several holes may be drilled at a single site by pulling the drill pipe above the seafloor (out of one hole), moving the ship $100 \mathrm{~m}$ or more from the previous hole, and then drilling another hole.

A letter suffix distinguishes additional holes drilled at the same site. The first hole takes only the site number; the second takes the site number with suffix $\mathrm{A}$; the third takes the site number with suffix B, and so forth. It is important, for sampling purposes, to distinguish the holes drilled at a site, because recovered sediments or rocks from different holes usually do not come from equivalent positions in the stratigraphic column.

The cored interval is measured in meters below the seafloor. The depth interval of an individual core is the depth below seafloor that the coring operation began to the depth that the coring operation ended. Each coring interval is generally $9.5 \mathrm{~m}$ long, which is the nominal length of a core barrel; however, the coring interval may be shorter. "Cored intervals" are not necessarily adjacent to each other, but may be separated by "drilled intervals". In soft sediment, the drill string can be "washed ahead" with the core barrel in place, but not recovering sediment, by pumping water down the pipe at high pressure to wash the sediment out of the way of the bit and up the space between the drill pipe and wall of the hole. Occasionally, if thin, hard rock layers are present, it is possible to retain samples of these resistant layers within the washed interval, producing a core longer than $9.5 \mathrm{~m}$.

Cores taken from a hole are numbered serially from the top of the hole downward. Full recovery for a single core is normally $9.28 \mathrm{~m}$ of sediment or rock in a plastic liner $(6.6 \mathrm{~cm}$ inner diameter), plus about a $0.2-\mathrm{m}$ sample (without a plastic liner) in the core catcher. The core 
catcher is a device at the bottom of the core barrel; it prevents the core from sliding out when the barrel is being retrieved from the hole. The sediment core, which is in the plastic liner, is cut into $1.5-\mathrm{m}$ sections and numbered serially from the top of the sediment core (Fig. 1). When full recovery is obtained, the sections are numbered from 1 through 7 , the deepest section possibly being shorter than $1.5 \mathrm{~m}$. The core catcher sample is placed below the last section when the core is described, and labeled core catcher (CC); it is treated as a separate section (for sediments only).

When recovery is less than $100 \%, 1.5$-m sections are numbered serially, starting with Section 1 at the top. There will be as many sections as are needed to accommodate the length of the core recovered (Fig. 1); for example, $3 \mathrm{~m}$ of core sample in plastic liners will be divided into two $1.5-\mathrm{m}$ sections. The last section may be shorter than the normal $1.5 \mathrm{~m}$.

When recovery is less than $100 \%$, the original stratigraphic position of the sediment in the cored interval is unknown; we attribute the top of the recovered sediment to the top of the cored interval. This convention is for convenience in data handling, and for consistency. If recovery is less than $100 \%$, if the core is fragmented, and if shipboard scientists believe that the fragments were not originally contiguous, then sections are numbered serially and the intervening sections are noted as void, whether the fragments as found were contiguous or not.

Samples are designated by distances in centimeters from the top of each section to the top and bottom of the sample in that section. A full identification number for a sample consists of the following information: leg, site, hole, core, section, and interval in centimeters. For example, the sample identification number " $72-516 \mathrm{~F}$ $30-3,98-100 \mathrm{~cm}$ " means that a sample was taken between 98 and $100 \mathrm{~cm}$ from the top of Section 3 of Core 30 , from the seventh hole drilled at Site 516 during Leg 72. A sample from the core catcher of this core might be designated " $72-516 \mathrm{~F}-30, \mathrm{CC}, 8-9 \mathrm{~cm}$."
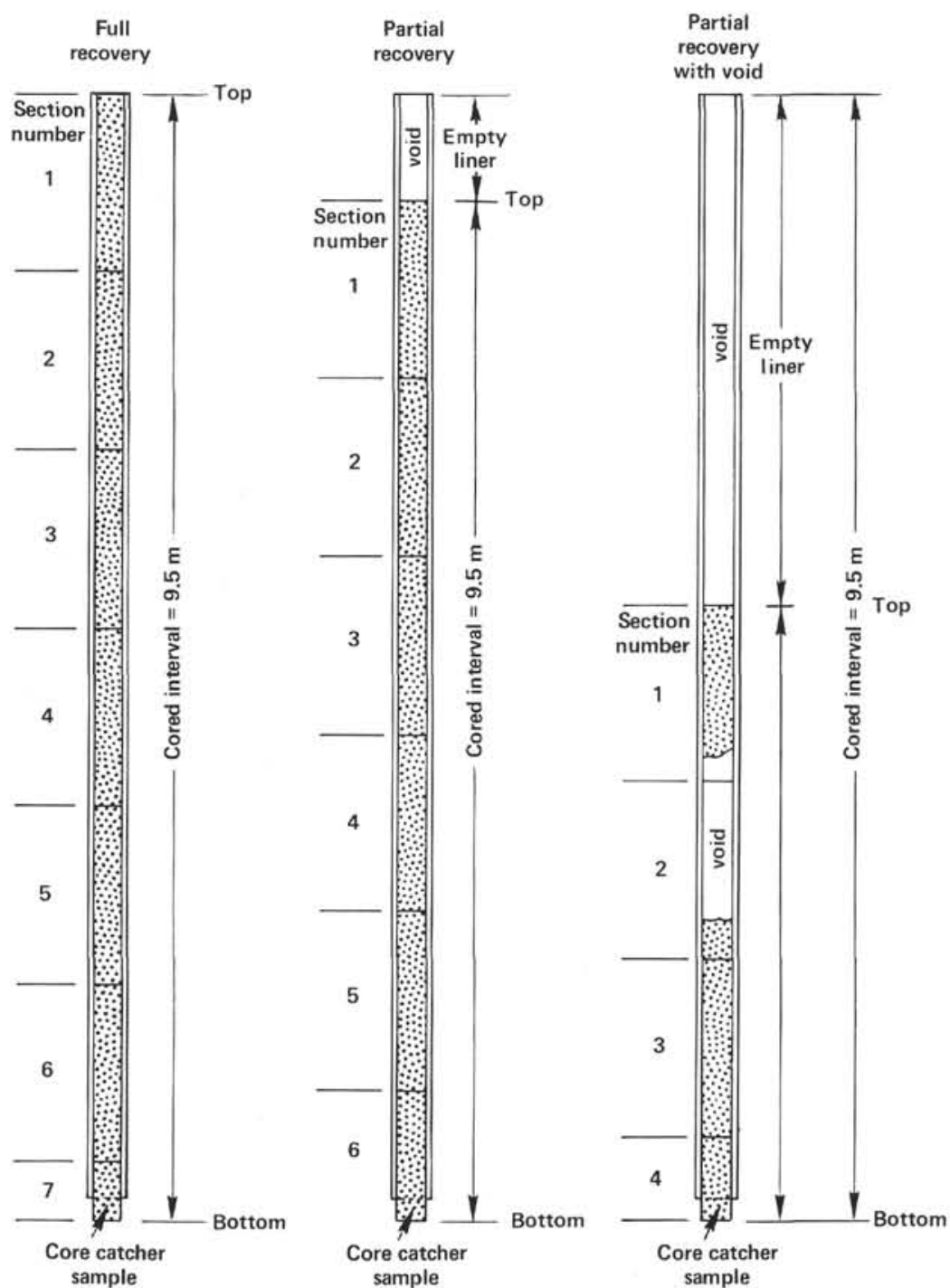

Figure 1. Cutting and labeling procedure for core sections. 
The depth below the seafloor for a sample numbered " $72-516 \mathrm{~F}-30-3,98-100 \mathrm{~cm}$ " is the sum of the depth to the top of the cored interval for Core $30(444.6 \mathrm{~m})$ and the $3 \mathrm{~m}$ included in Sections 1 and 2 (each $1.5 \mathrm{~m}$ long) and the $98 \mathrm{~cm}$ below the top of Section 3. The sample in question is located at $448.58 \mathrm{~m}$ sub-bottom, which in principle is the sample depth below the seafloor (sample requests should refer to a specific interval within a core section, rather than the depth below seafloor).

Conventions regarding the cataloging of the cores recovered by the hydraulic piston corer (HPC) are the same as those for the rotary cores, except that the maximum stroke-length was only $4.4 \mathrm{~m}$ during Leg 72 . A full HPC core, therefore, consists of two sections, each $1.5 \mathrm{~m}$ long, a third section of variable length, and a core catcher as much as $0.2 \mathrm{~m}$ long. For details regarding the HPC operation, core orientation, and special HPC features see Prell and others (1982).

\section{Handling of Cores}

A core is normally cut into $1.5-\mathrm{m}$ sections, sealed, and labeled on the rig floor; the sections are then brought into the core laboratory for processing. The following determinations are normally made before the sections are split: gas analysis, thermal-conductivity analysis (soft sediment only), and continuous wet-bulk density determinations using the Gamma Ray Attenuation Porosity Evaluator (GRAPE).

The cores are then split longitudinally into working and archive halves, either by wire cutter, or by "super saw". The contrast in appearance between cores cut by the two methods can be significant. Samples extracted from the working half include those for measurement of sonic velocity by the Hamilton Frame method, measurement of wet-bulk density by a GRAPE technique, carbon-carbonate analysis, measurement of carbonate percentage (carbonate bomb), geochemical analysis, paleontologic studies, and other studies. When sufficiently firm, the archive half is washed on the cut surface to emphasize the sedimentary features. The color, texture, structure, and composition of the various lithologies within a section are described on standard visual-coredescription sheets (one per section), and any unusual features are noted. During Leg 72, a smear slide was made, usually from the first section of each core at $50 \mathrm{~cm}$, if the core was uniform. Two or more smear slides were often made for each area of distinct lithology in the core section. The smear slides were examined by petrographic microscope, and then the archive half of the core section was photographed.

After the cores are sampled and described, they are maintained in cold storage aboard Glomar Challenger until transferred to the DSDP repository. Core sections removed for organic-geochemistry studies are frozen immediately aboard ship and kept frozen. All Leg 72 cores and frozen cores are presently stored at the DSDP East Coast Repository (Lamont-Doherty Geological Observatory).

Visual core descriptions, smear slide descriptions, and carbonate-bomb (percent $\mathrm{CaCO}_{3}$ ) determinations (all done aboard ship) provide the data for the core descrip- tions in this volume. This information is summarized and sample locations in the core are indicated on the core description sheets (Fig. 2).

\section{Sediments and Sedimentary Rocks Core Description Forms}

\section{Drilling Disturbance}

Recovered rocks, particularly soft sediments, may be extremely disturbed. This mechanical disturbance is a result of the coring technique, which uses a bit $25 \mathrm{~cm}$ in diameter with a 6-cm diameter opening for the core sample. Symbols for six disturbance categories used for soft and firm sediment are shown on the core description form in the "Drilling Disturbance" column (Fig. 2). The disturbance categories are defined as: (1) slightly deformed: bedding contacts are slightly bent; (2) moderately deformed: bedding contacts have undergone extreme bowing, and firm sediment is fractured; (3) very deformed: bedding is completely disturbed or homogenized by drilling, sometimes showing symmetrical diapirlike structure; (4) soupy: water-saturated intervals that have lost all aspects of original bedding; (5) biscuited: sediment firm and broken into chunks about $5-10 \mathrm{~cm}$ long; and (6) brecciated: indurated sediments broken into angular fragments by the drilling process, perhaps along preexisting fractures.

\section{Sedimentary Structures}

In the soft, and even in some harder, sedimentary cores, it may be extremely difficult to distinguish between natural structures and structures created by the coring process, and in these instances the description of sedimentary structures is optional. Locations and types of structures appear as graphic symbols in the "Sedimentary Structures" column on the core description form (Fig. 2). Figure 3 gives the key for these symbols.

\section{Color}

Colors of the core samples are determined with the Geological Society of America Rock-Color Chart (Munsell Soil Color Charts, 1971). Colors were determined immediately after the cores were split and while they were still wet.

\section{Lithology}

The graphic column on the core description form is based on the lithologies, and the sediment represented by a single pattern or by a grouping of two or more symbols (Fig. 4). The symbols in a grouping correspond to end-members of sediment compositional range, such as clay or nannofossil ooze. The symbol for the terrigenous constituent appears on the right-hand side of the column, the symbol for the biogenic constituent(s) on the left-hand side of the column. The abundance of any component approximately equals the percentage of the width of the graphic column its symbol occupies. For example, the left $20 \%$ of the column may have a diatom ooze symbol, whereas the right $80 \%$ may have a silty clay symbol, indicating sediment composed of $80 \%$ mud and $20 \%$ diatoms. 
W. T. COULBOURN

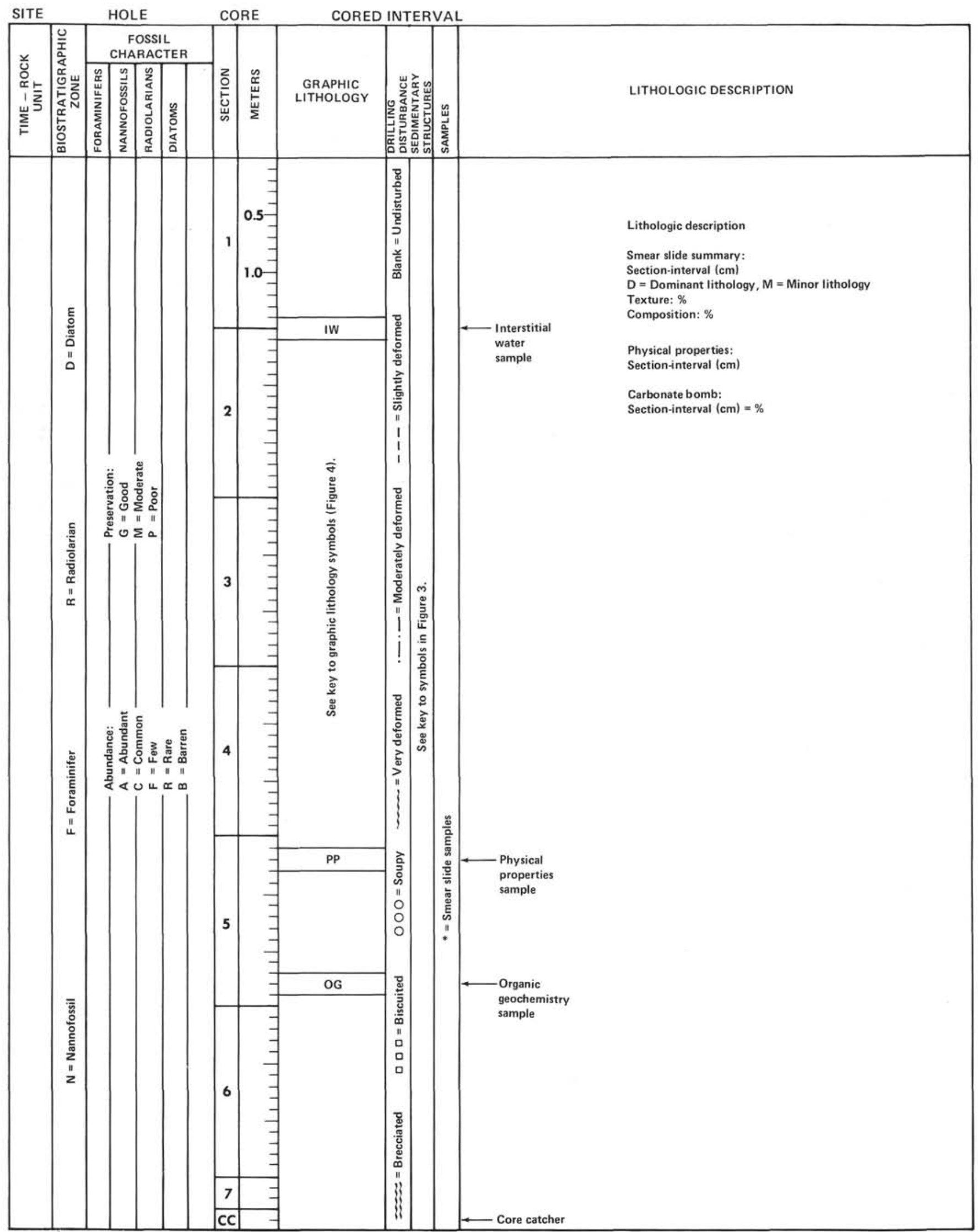

Figure 2. Sample core form for description of sediment (barrel sheet). 


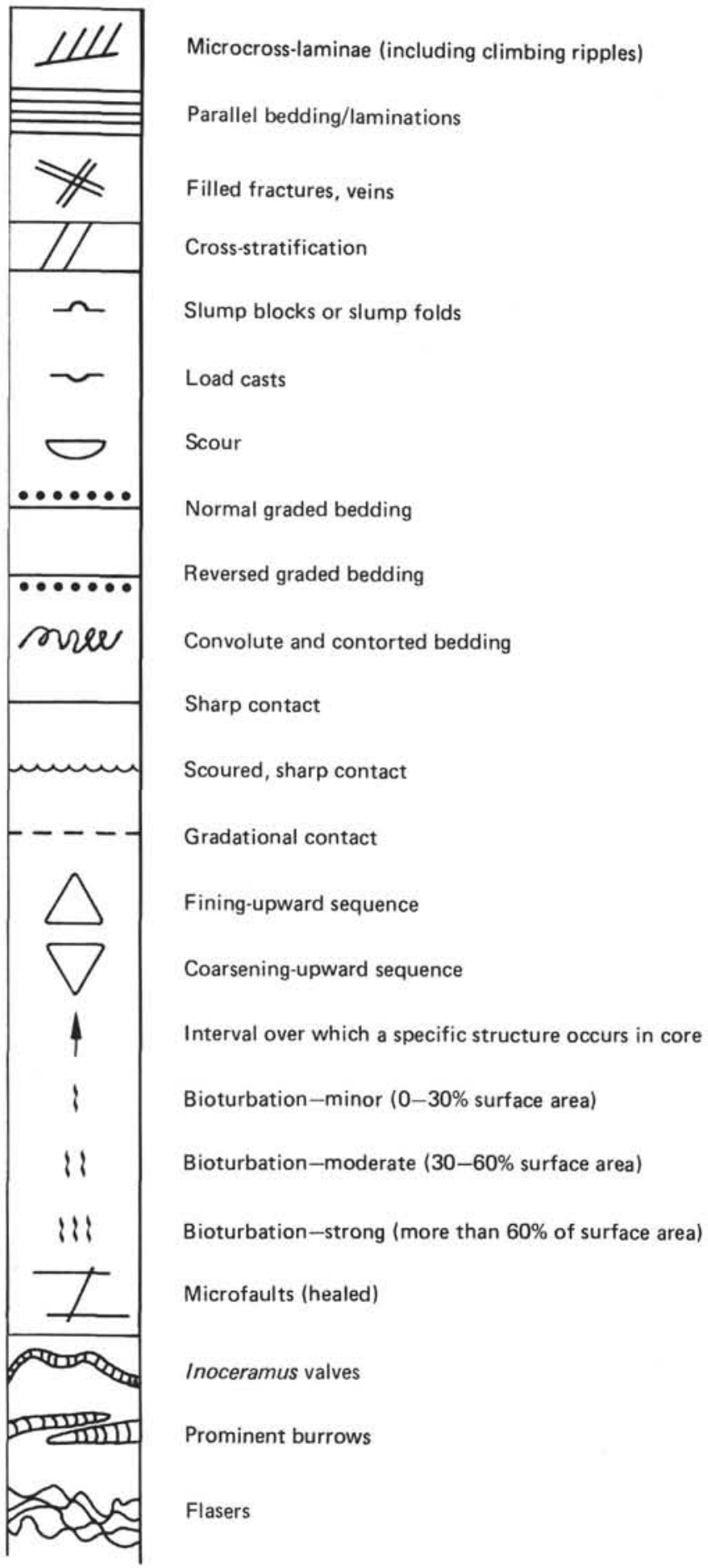

Figure 3. Symbols of sedimentary structures used on core description forms (sediment).

Because of the difference in the length-to-width ratio between the actual sediment core and the graphic lithologic column, it is not possible to reproduce structures as they appeared in the core; in the graphic representation they are highly flattened and distorted. The same is true for rock fragments or pebbles in the cores.

In special cases on Leg 72, when the core was recovered in excellent condition and also contained an abun- dance and variety of special features, the graphic lithology was carefully hand-drawn as the sections were processed on shipboard. Some artistic license was taken in the presentation of dipping beds, color changes, flasers, and burrows (see site chapter, Site 516, this volume). The spacing of patterned blocks (CODE CB9, Fig. 4) for Hole $516 \mathrm{~F}$ is intended to convey meaning: wide spacing indicates relatively pure limestone, close spacing identifies marly intervals.

Smear-slide (or thin-section) compositions, carbonate content (percent $\mathrm{CaCO}_{3}$ ), and organic carbon content determined on board are listed below the core description; the two numbers separated by a hyphen refer to the section and centimeter interval, respectively, of the sample. The locations of these samples in the core and a key to the codes used to identify these samples are given in the "Samples" column (Fig. 2). The locations and intervals of the organic geochemistry, interstitial water, and physical property samples are given in the lithology column.

\section{Lithologic Classification of Sediments}

The basic classification system used here was devised by the JOIDES Panel on Sedimentary Petrology and Physical Properties and adopted for use by the JOIDES Planning Committee in March 1974. This classification is descriptive rather than generic, and divisions between different types of sediment are somewhat arbitrary (Fig. 5). We treat lithologic types not covered in this classification as a separate category termed Special Rock Types. A brief outline of the conventions and descriptive data used to construct this classification follows.

\section{Composition and Texture}

In this classification, composition and texture are the only criteria used to define the type of sediment or sedimentary rock. Composition is more important for describing sediments deposited in the open ocean, and texture becomes significant for hemipelagic and nearshore sediments. These data come principally from visual analyses of smear slides with a petrographic microscope. They are estimates of abundance and size of the components on a slide and may differ somewhat from more accurate analyses of grain size, carbonate content, and mineralogy presented in related shore-based studies (this volume). Past experience indicates that quantitative estimates of distinctive minor components are accurate to within $1-2 \%$, but that accuracy for major constituents is poorer, $\pm 10 \%$. All smear slide estimates were done on board.

When applicable, one or several modifiers were used to name the type of sediment encountered. In all cases the dominant component appears last in the name; minor components precede, with the least common constituent listed first. Minor constituents occurring in amounts less than $10 \%$ are not included in the name. This convention also holds for zeolites, iron and manganese-micronodules, and other indicators of very low rates of sedimentation or nondeposition, such as fish teeth. Often these minerals are conspicuous, even though greatly diluted. If deemed important, as graded beds and Inoceramus were on Leg 72, they are sometimes in- 


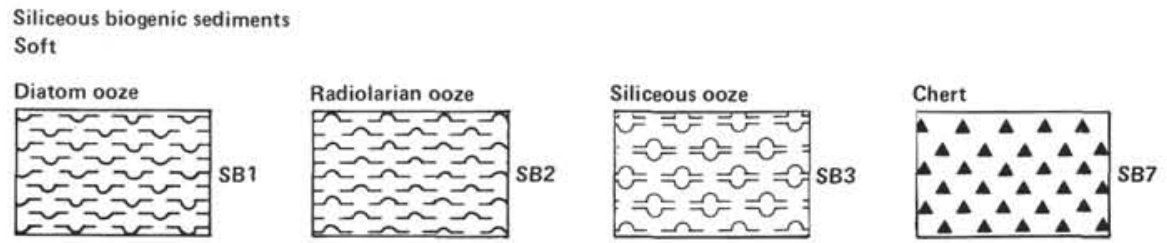

Transitional siliceous terrigenous sediments
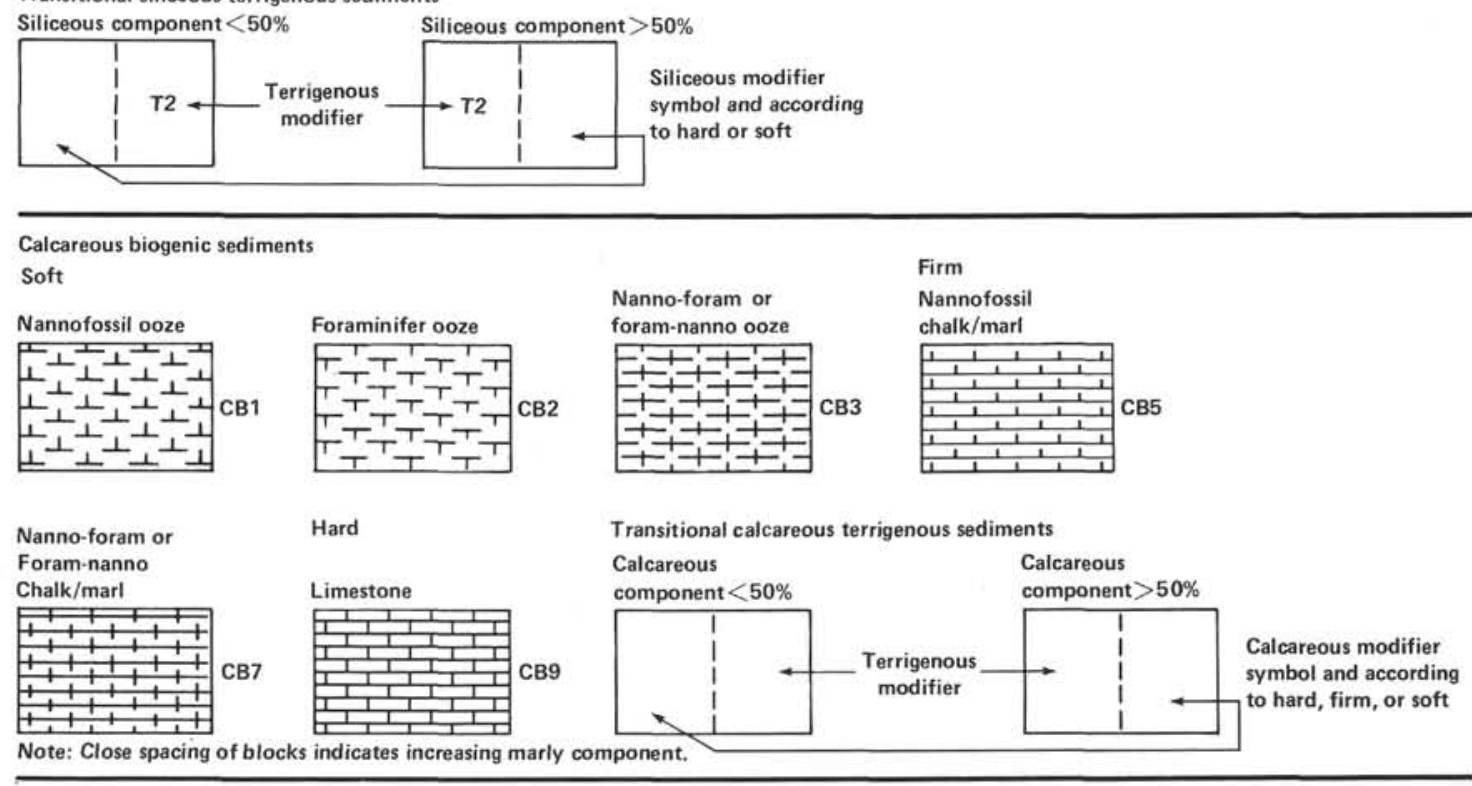

Terrigenous sediments
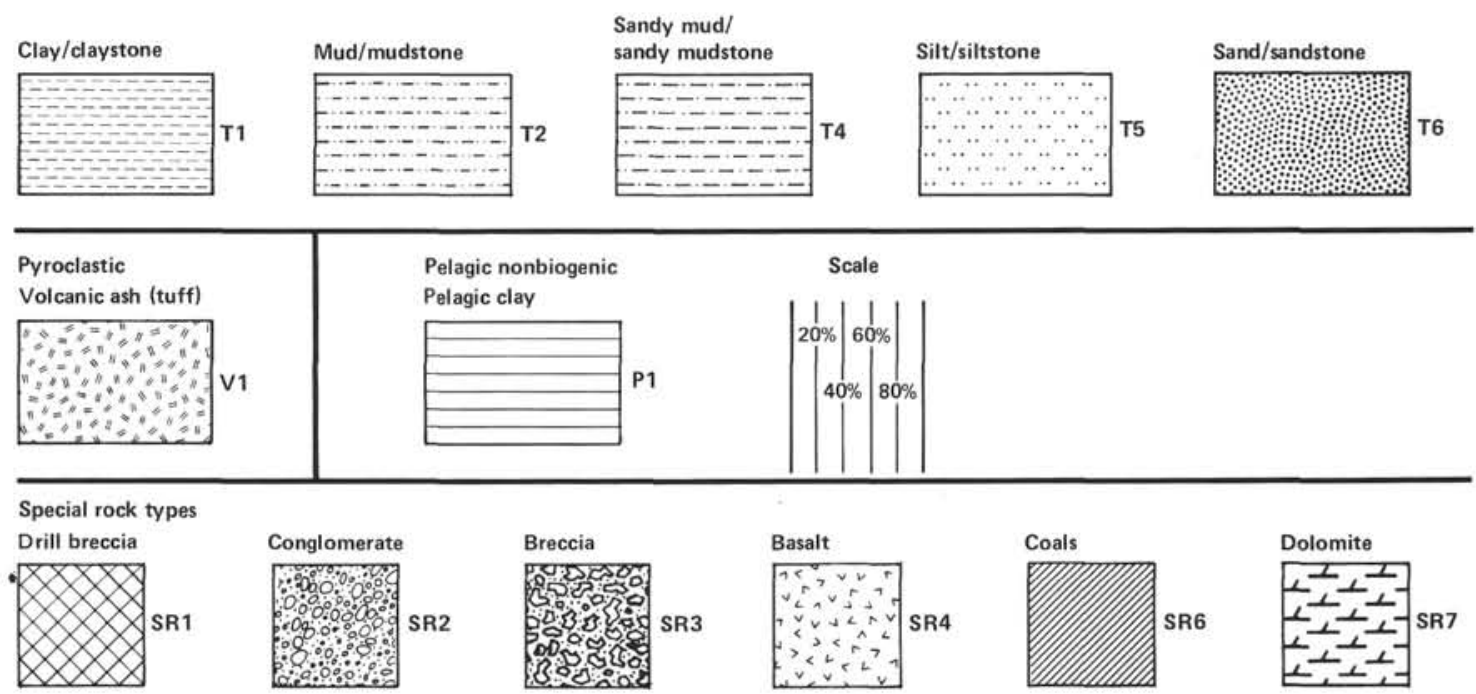

Figure 4. Symbols used in graphic lithology columns of core description form (sediment).

cluded in the name of the sediment or mentioned in the lithologic description.

\section{Induration of Sediments}

We recognize three classes of induration or lithification for all sediments:

1) Calcareous sediments and sedimentary rocks, categories after Gealy and others (1971): (1) soft = ooze; has little strength and is readily deformed under pressure of finger or broad blade of spatula; (2) firm = chalk; partially lithified, readily scratched with fingernail or edge of spatula; (3) hard = limestone, dolostone, well lithified and cemented, resistant or impossible to scratch with fingernail or edge of spatula.

2) The three classes of induration for transitional carbonates, siliceous, pelagic, and terrigenous sediments are as follows: (1) soft = sediment core may be split with wire cutter; (2) firm = partially lithified but fingertip pressure leaves an indentation; (3) hard = cannot be compressed with fingertip pressure. 

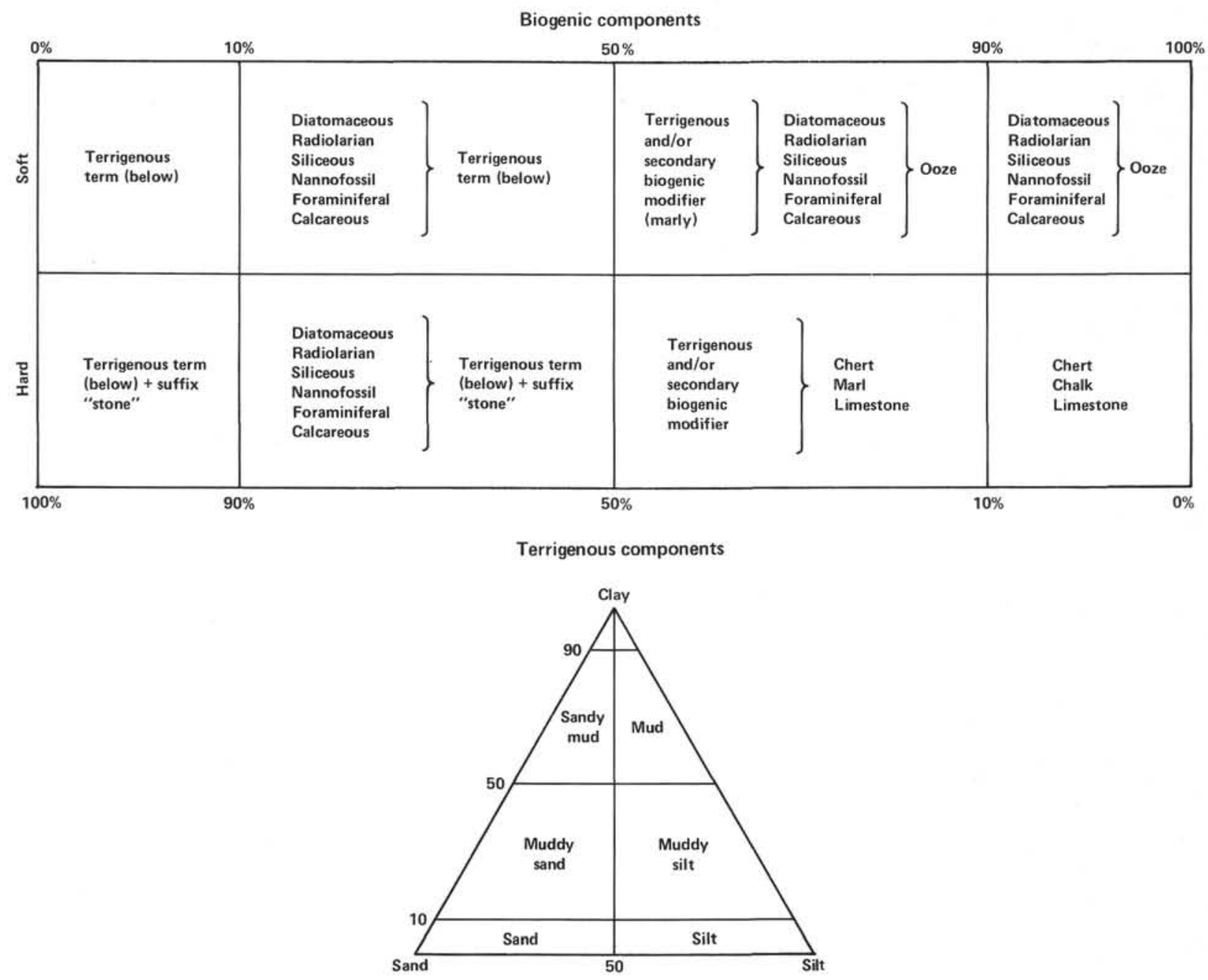

Figure 5. Textural classification of clastic sediments.

\section{Types of Sediments and Sedimentary Rocks, Compositional Boundaries}

\section{Pelagic Clay}

Pelagic clay is principally an authigenic pelagic deposit that accumulates at very slow rates. The class has also often been termed brown clay or red clay.

1) Boundary of pelagic clay with terrigenous sediment occurs where authigenic components (Fe/Mn micronodules, zeolites), fish debris and other microfossil constituents reach $10 \%$ in smear slides, greater percentages indicating pelagic clay. Because the accumulation rates of pelagic clay and terrigenous sediments are very different, transitional deposits are exceptional.

2) Boundary of pelagic clay with siliceous biogenic sediments occurs where siliceous remains make up $30 \%$ of the content.

3) Boundary of pelagic clay with calcareous biogenic sediment is uncommon. Generally this facies passes from pelagic clay through siliceous ooze to calcareous ooze, with one important exception: at the base of many oceanic sections, black, brown, or red clays occur directly on basalt, overlain by or grading up into calcareous sediments. Most of the basal clayey sediments are rich in iron, manganese, and other metallic trace elements.

\section{Pelagic Siliceous Biogenic Sediment}

Pelagic siliceous biogenic sediment is distinguished from pelagic clay by having more than $30 \%$ siliceous microfossils. Siliceous biogenic sediments are distinguished from calcareous biogenic sediments by a calcium carbonate content of less than $30 \%$.

For a pelagic biogenic siliceous sediment with 30 $100 \%$ siliceous fossils, the following terminology is used: (1) soft: siliceous ooze (radiolarian ooze or diatomaceous ooze, depending on the dominant fossil component); (2) hard: radiolarite, diatomite, chert, or porcellanite; (3) compositional qualifiers: diatoms and radiolaria may be the principal components, thus one or two qualifiers may be used. The order of the two qualifiers in the terms is dependent on the dominant fossil type. The dominant component is listed last and the minor component first.

\section{Pelagic Biogenic Calcareous Sediment}

Pelagic calcareous sediment is distinguished by a biogenic $\mathrm{CaCO}_{3}$ content in excess of $30 \%$. There are two 
classes: (1) pelagic biogenic calcareous sediments that contain $60-100 \%$ biogenic $\mathrm{CaCO}_{3}$ and (2) transitional biogenic calcareous sediments that contain $30-60 \%$ $\mathrm{CaCO}_{3}$.

For the pelagic biogenic calcareous sediment with 60 $100 \% \mathrm{CaCO}_{3}$, the following terminology is used: soft for calcareous ooze; firm for chalk; hard and cemented for limestone; compositional qualifiers (if nannofossils and foraminifers are the principal components, then one or two qualifiers were used).

The transitional biogenic calcareous sediments with $30-60 \% \mathrm{CaCO}_{3}$ are termed marl or marlstone, depending on whether they are soft or hard.

\section{Terrigenous Sediment}

Terrigenous sediments are distinguished by a terrigenous component in excess of $30 \%$ and by siliceous and authigenic components each less than $10 \%$. Sediments in this category are subdivided into textural groups by smear slide estimation or grain-size analysis on the basis of the relative proportions of sand, silt, and clay. The size limits are those defined by Wentworth (1922). Textural classification follows the triangular diagram (Fig. 5).

\section{Hemipelagic Sediment}

The transition between pelagic and terrigenous sediments is termed hemipelagic. These sediments are distinguished by a terrigenous component in excess of $30 \%$, a total nonbiogenic component in excess of $40 \%$, and a biogenic content in excess of $10 \%$. Besides the terrigenous component, hemipelagic sediments are usually rich in biogenic silica (usually diatoms, because of coastal upwelling) and volcanic ash (predominantly along active margins). These sediments were not encountered during Leg 72 .

\section{Volcanogenic Sediment}

Pyroclastic rocks are described according to the textural and compositional scheme of Wentworth and Williams (1932). The textural groups are: more than $32 \mathrm{~mm}$-volcanic breccia, 32 to $4 \mathrm{~mm}$-volcanic lapilli, and less than $4 \mathrm{~mm}$ - volcanic ash (tuff when indurated). The composition of these pyroclastic rocks is described as vitric (glass), crystalline, or lithic.

Sediments rich in ash are described in the following manner:

\begin{tabular}{rll}
\hline $\begin{array}{c}\text { Ash } \\
(\%)\end{array}$ & $\begin{array}{c}\text { Soft } \\
\text { sediment }\end{array}$ & \multicolumn{1}{c}{ Indurated } \\
\hline $0-10$ & Mud & Mudstone \\
$10-30$ & Vitric mud & Vitric mudstone \\
$30-60$ & Muddy ash & Tuffite \\
$>60$ & Ash & Tuff \\
\hline
\end{tabular}

\section{Special Sedimentary Rock Types}

The definition and nomenclature of sediment and rock types not included in the system described above are left to the discretion of shipboard scientists, with the recommendation that they adhere as closely as is practi- cal to conventional terminology. In this category fall such rocks as: evaporites (halite, anhydrite, and gypsum); shallow-water limestone (biostromal, biohermal, coquina, and oolite); dolomite; and gravels, conglomerates, and breccias.

\section{Qualifiers}

In general, sediment constituents in the $10-30 \%$ range may be identified in the name of sediment (e.g., vitric diatomaceous mud or vitric muddy diatomaceous ooze). If more than one such qualifier is used, they are listed in order of increasing abundance in the sediment.

\section{Biostratigraphy and Basis for Age Determination}

As a result of the nearly continuous depositional record recovered at Site 516, we were able to make substantial refinements in the correlation of magnetostratigraphic and biostratigraphic datum levels. For the Neogene, these correlations are shown in the chapter by Berggren, Aubry, and Hamilton (this volume). For the Paleogene and Late Cretaceous, the correlation scheme is shown as Figure 2 of Berggren, Hamilton, et al. (this volume). These correlation charts have been constructed as follows. For foraminifers, the zonation of Berggren $(1973 ; 1977 \mathrm{a}, \mathrm{b})$ is used for the Pliocene; that of Blow (1969) is retained for other Neogene sequences; and that of Stainforth and others (1975) for the Paleogene sequence. Perch-Nielsen's (1977) zonation of nannofossils is used primarily and is correlated with the scheme of van Hinte (1976). Riedel and Sanfilippo $(1971,1978)$ radiolarian zones are used. For diatoms, the zones of Gombos and Ciesielski (in press) are used.

The following letters are used on core description sheets to indicate fossil abundance:

$\mathrm{A}=$ abundant (flood, many species and specimens)

$\mathrm{C}=$ common (many species, easy to make age assignment)

$\mathrm{F}=$ few (scattered occurrences of diagnostic taxa)

$\mathrm{R}=$ rare (enough for age assignment)

$\mathrm{T}=$ trace (few species and specimens, not enough for age assignment)

$\mathrm{B}=$ barren

Letters used to designate fossil preservation are:

$\mathrm{E}=$ excellent (no dissolution or abrasion)

$\mathrm{G}=$ good (very little dissolution or abrasion)

$\mathbf{M}=$ moderate (dissolution and/or abrasion and/or recrystallization very noticeable)

$\mathbf{P}=$ poor (substantial or very strong evidence of dissolution and/or abrasion, and/or recrystallization)

\section{Shipboard Geochemical Measurements}

\section{Carbonate Bomb}

Percent $\mathrm{CaCO}_{3}$ was also determined on shipboard by the "Karbonate Bombe" technique (Müller and Gastner, 1971). In this simple procedure, a sample is ground to powder and treated with $\mathrm{HCl}$ in a closed cylinder. Any resulting $\mathrm{CO}_{2}$ pressure is proportional to the $\mathrm{CaCO}_{3}$ content of the sample. Application of the calibration factor to the manometer reading $(\times 100)$ yields percent $\mathrm{CaCO}_{3}$. Percent error can be as low as $1 \%$ for 
sediments high in $\mathrm{CaCO}_{3}$, and in general an accuracy of about $2-5 \%$ can be obtained.

These data are presented on the core-description sheets (Fig. 2). The sample interval is designated by two numbers: the section number, followed by the top of the sample interval. For example, a sample from Section 2, 11 to $12 \mathrm{~cm}$, with $90 \%$ calcium carbonate will be represented on the core description sheet as " $2-11(90 \%)$."

\section{Other Geochemical Analyses}

Aboard-ship analyses for carbon-carbonate, $\mathrm{pH}$, alkalinity, salinity, calcium, magnesium, and chlorinity are conducted routinely. A limited number of carboncarbonate analyses are made using a LECO WR-12 Carbon Analyzer. Sample preparation includes drying, grinding (with a Diamonite mortar and pestle), and weighing out of two 0.1-g samples. One of these is analyzed for total carbon after wetting with deionized water and drying. The other, analyzed for organic carbon, is acidified to remove the acid soluble components, dried, and analyzed. Reproducibility tests are not run, but the total carbon and organic carbon analyses should be near $\pm 4 \%$ (relative) and the carbonate about $\pm 2 \%$ (absolute).

Interstitial waters are routinely analyzed for $\mathrm{pH}$, alkalinity, salinity, calcium, magnesium, and chlorinity. Sediments are squeezed using a stainless steel press; the water collects in plastic syringes and is then filtered through $0.45-\mu \mathrm{m}, 1$-inch millipore filters. Interstitial waters collected with the In Situ Water Sampler are filtered through $0.4-\mu \mathrm{m}, 13-\mathrm{mm}$ filters before analysis.

A Corning Model $130 \mathrm{pH}$ meter and a Markson combination electrode were used to determine $\mathrm{pH}$. The $\mathrm{pH}$ meter is calibrated with 4.01 and 7.42 buffer standards, all readings are originally in millivolts and later are converted to $\mathrm{pH}$. All $\mathrm{pH}$ measurements are made in conjunction with alkalinity measurements.

Alkalinities are determined potentiometrically. The samples $(5-10 \mathrm{ml}$ in size) are first tested for $\mathrm{pH}$ then titrated with $0.1 \mathrm{~N} \mathrm{HCL}$. Near the endpoint, acid is added in 0.01 - $\mathrm{ml}$ or $0.005-\mathrm{ml}$ increments, and the millivolt readings noted for each increment. The exact endpoint is then calculated by the Gran Factor method (Gieskes and Rogers, 1973).

Salinity is calculated from the fluid refractive index, as measured by a Goldberg optical refractometer, using this expression:

$$
\text { Salinity }(\%)=0.55 \times \Delta \mathrm{N} \text {, }
$$

where $\Delta \mathrm{N}$ is the refractive index multiplied by $10^{4}$. The refractometer's calibration is checked periodically using the IAPSO standard seawater and deionized water.

Calcium is determined by titrating a $0.5-\mathrm{ml}$ sample with EGTA (a complexing agent); GHA is used as an indicator. To sharpen the endpoint, the calcium-GHA complex is extracted into a layer of butanol. No correction is made for strontium, which is also included in the result.

Magnesium is determined by titrating a buffered 0.5-ml sample to an Ereochrome Black-T endpoint, us- ing EDTA (sodium salt) as a titrant. This method analyzes all alkaline earths, including calcium, magnesium, strontium, and magnesium; concentrations are obtained by subtracting the calcium (which includes strontium) from this analysis.

Chlorinity is determined by titrating a $0.1-\mathrm{ml}$ sample diluted with $1 \mathrm{ml}$ of deionized water, with silver nitrate to a potassium chromate endpoint.

Methods and equipment are checked and standardized at each site using IAPSO standard seawater. As a further check, a surface seawater sample is also analyzed and archived. This sample is also used to test for possible drill water contamination of the interstitial water samples.

\section{Physical Properties-Procedures}

A thorough discussion of measurement procedures for physical properties is presented by Boyce (1976), including descriptions of equipment, methods, errors, correction factors, and problems related to coring disturbance. Only a brief review of methods employed on Leg 72 is given here.

\section{Velocity}

Compressional-wave velocities were measured on the Hamilton Frame Velocimeter by timing a $400-\mathrm{kHz}$ pulse between two transducers and by measuring the distance across the sample with a dial gauge. Velocities in unconsolidated sediments were generally measured on the split core; correction factors established by Boyce (1976) were used to compensate for increased thickness and travel time caused by the polycarbonate liner $(0.242-\mathrm{cm}$ and $1.108-\mu$ s thick, respectively). For consolidated sediments, a piece was removed from the core and trimmed carefully to form two parallel surfaces to ensure good contact with the transducer heads. Salt water was used to make an acoustic contact between the sample and the transducers.

Calibration measurements were made with a lucite standard having an assumed velocity of $2.745 \mathrm{~mm} / \mu \mathrm{s}$ and a length of $31.84 \mathrm{~mm}$. The corresponding calculated travel time was $11.60 \mu \mathrm{s}$. Twenty measurements were made with a Tektronix 485 oscilloscope, and thickness measurements of the lucite standard were made with a dial gauge integral to the Hamilton Frame. The average length was $31.74 \mathrm{~mm}$, approximately $0.04 \mathrm{~mm}$ less than expected. The observed average travel time was 11.596 $\pm 0.073 \mathrm{~s}$. The calculated lucite velocity was $2.735 \pm$ $0.018 \mathrm{~mm} / \mu \mathrm{s}$. The accuracy of the Hamilton Frame velocity device was $0.4 \%$, which can be stated as $0.7 \%$ precision. A calibration constant, or correction factor, was not used on shipboard velocity measurements.

\section{GRAPE}

The Gamma Ray Attenuation and Porosity Evaluator (GRAPE) was used to determine wet-bulk density based on the attenuation of gamma rays by the sample. Boyce (1976) discusses the theoretical aspects in detail. During Leg 72, the GRAPE was used in two modes: (1) continuous GRAPE, in which most sections of the core were irradiated, and continuous "corrected" wet-bulk 
density (relative to quartz) was plotted on an analog graph; and (2) 2-minute GRAPE, in which the gamma count through a small piece of the core was measured for 2 minutes, followed by a similar count through air and/or a quartz standard.

\section{Continuous GRAPE}

Before each core was run through the device, an aluminum standard was measured. An equivalent density of $2.60 \mathrm{Mg} / \mathrm{m}^{3}$ was assigned to the $6.61-\mathrm{cm}$ (diameter) aluminum standard analog record and a density of $1.0 \mathrm{Mg} / \mathrm{m}^{3}$ to the $2.54-\mathrm{cm}$ (diameter) aluminum standard analog record. Linear interpolation of the GRAPE analog data between these values yields an "empirical" wet-bulk density of the sediment sample in the core $\left(\varrho_{b c z}\right)$. If the sediment completely fills the core, then $\varrho_{b c}$ $=$ "corrected" wet-bulk density (relative to quartz). Then:

$$
\varrho_{\mathrm{b}}=\frac{\left(\varrho_{\mathrm{bc}}-\varrho_{\mathrm{fc}}\right)\left(\varrho_{\mathrm{g}}-\varrho_{\mathrm{f}}\right)}{\left(\varrho_{\mathrm{gc}}-\varrho_{\mathrm{fc}}\right)}+\varrho_{\mathrm{f}}
$$

where $\varrho_{\mathrm{g}}=$ true grain density $\left(\sim 2.71 \mathrm{Mg} / \mathrm{m}^{3}\right.$ for calcareous sediments, and $\sim 2.80 \mathrm{Mg} / \mathrm{m}^{3}$ for terrigenous clays, Mitchell, 1976); $\varrho_{\mathrm{gc}}=$ salt-corrected grain density assumed equal to $\varrho_{\mathrm{g}} ; \varrho_{\mathrm{f}}=$ true fluid density $(\sim 1.025$ $\left.\mathrm{Mg} / \mathrm{m}^{3}\right) ; \varrho_{\mathrm{fc}}=$ salt-corrected fluid density $(\sim 1.128 \mathrm{Mg} /$ $\mathrm{m}^{3}$ ); and $\varrho_{\mathrm{b}}=$ true wet-bulk density.

Using the above values for calcareous sediments,

$$
\varrho_{b}=1.065\left(\varrho_{b c}-1.128\right)+1.025 ;
$$

for terrigenous clay deposits,

$$
\varrho_{b}=1.062\left(\varrho_{b c}-1.128\right)+1.025 .
$$

The porosity $\phi$ is obtained by

$$
\phi(\%)=\frac{\varrho_{\mathrm{g}}-\varrho_{\mathrm{b}}}{\varrho_{\mathrm{g}}-\varrho_{\mathrm{f}}} \times 100 .
$$

No corrections are made for core samples that did not fill the liner.

\section{Two-Minute GRAPE}

For 2-minute GRAPE calculations,

$$
\varrho_{\mathrm{bc}}=\frac{\ln \left(I_{\mathrm{o}} / I\right)}{d \mu \mathrm{qtz}},
$$

where $I_{\mathrm{o}}=2$-minute gamma count through air, $I=$ 2-minute gamma count through the sample, $d=$ gamma ray path length through the sample, and $\mathrm{qtz}=$ quartz attenuation coefficient determined daily by measuring through a quartz standard. Then, as in the continuous GRAPE calculation (assuming a 2.71 grain density),

$$
\varrho_{b}=1.066\left(\varrho_{b c}-1.128\right)+1.025
$$

and

$$
\phi(\%)=\frac{100\left(2.71-\varrho_{b}\right)}{1.685} .
$$

Boyce (1976) estimates $\pm 5 \%$ accuracy for continuous GRAPE data and $\pm 2 \%$ for 2 -minute GRAPE data. In practice, it was found that the error on Leg 72 seemed to be higher, partly because of the highly disturbed nature of many of the cores and partly because of errors in gamma ray travel-path determinations caused by swelling of the sediments. Good agreement exists, however, between the GRAPE data from selected portions (as just described) of nearly every section and the gravimetric methods (syringe and rock chunk).

\section{Gravimetric Technique: Syringe and Rock Chunk}

In a soft sediment (recovered from less than $150 \mathrm{~m}$ sub-bottom), a $1-\mathrm{cm}^{3}$ syringe was used to collect a measured volume of sample for shipboard analysis. In harder sediments, a $10-30 \mathrm{~cm}^{3}$ chunk was collected. A small piece of this chunk was used for water content determination only; the remainder was used for a volume determination by immersion in water. Wet-bulk density, porosity, grain density, and water content were then determined. No salt corrections were applied in any of these techniques.

$$
\begin{gathered}
\begin{array}{c}
\text { Water content }(\% \text { wet wt. })= \\
\text { (wt. wet sediment })-(\text { wt. dry sediment })
\end{array} \\
\text { (wt. wet sediment); } \\
\text { Wet-bulk density }\left(\mathrm{Mg} / \mathrm{m}^{3}\right)=\frac{\text { wt. wet sediment }}{\text { vol. wet sediment }} .
\end{gathered}
$$

The $1-\mathrm{cm}^{3}$ syringe samples provide a volume measurement. Bennett and Keller (1973) note, however, that this volume is too small for accurate determinations of grain density and porosity. Results from Leg 72 confirm the inaccuracies of the syringe sampler. The method is also dependent upon sampling techniques; any cracks or voids in the sample lead to large inaccuracies. In addition, despite all precautions, some compression of almost all samples occurs, leading to inaccuracies in the volume measurements. Large samples taken for shorebased determinations provide more accurate results.

For syringe and rock chunk methods, porosity is computed as:

$$
\text { Porosity }(\%)=100 \times \frac{\text { wt. evaporated water }}{\text { vol. wet sediment }} .
$$

In general, the gravimetric techniques provide useful data for comparison with the GRAPE data. When good sampling techniques are followed (and good samples are available), the data generally compare well. Statistical analyses prove that 2-minute GRAPE count data (wetbulk densities) are $2 \%$ higher than gravimetric measurements. No large-diameter syringe samples were obtained because the necessary equipment was not available. 


\section{Shear Strength Measurements}

A CL-600 Torvane Soiltest Pocket Penetrometer and a Wykeham Farrance vane apparatus were used onboard to determine the undrained shear strength of both clayey and calcareous sediments obtained by hydraulic piston coring. The Torvane is hand-rotated at a rate designed to reach failure in about $10 \mathrm{~s}$ with constant loading. Repeated determinations yielded results that were generally reproducible to $\pm 10 \%$. Measurements were made in the least-disturbed sections of the split core, parallel to the core axis, and were discontinued when cracking of the sediments was observed, indicating failure by fracturing rather than by shear.

The Soiltest Pocket Penetrometer was pushed into undisturbed sections of the split core from Hole 515A. Penetrometer data provide unconfined compression strength data, $\mathrm{q}_{\mathrm{c}}$. Shear strength was related to shear strength by Terzaghi and Peck (1967):

$$
\tau_{\mathrm{p}}=\mathrm{q}_{\mathrm{c}} / 2,
$$

where $\tau_{\mathrm{p}}=$ shear strength at failure.

The Wykeham Farrance vane apparatus was used at Hole 515A. Measurements were made only on undisturbed sections of the split core with the vane axis parallel to bedding. A $1.28-\mathrm{cm}$ vane was inserted $1 \mathrm{~cm}$ into the (half) core and was rotated by a motor at $89^{\circ} / \mathrm{min}$ ute. Resistance springs were selected so that shearing occurred between 30 and $110^{\circ}$ stress. Shear strength was calculated by Boyce (1977) as:

$$
\tau_{\mathrm{f}}=c=\frac{2 t}{\pi \mathrm{d}^{2}\left(1+\frac{2}{3 \mathrm{~h}}\right)} \text { (maximum degree spring stress), }
$$

where $\tau_{\mathrm{f}}=c=$ cohesion and shear strength of clay at failure, $t=$ spring torque factor in $\mathrm{gcm} /$ degree, $\mathrm{d}=\mathrm{di}$ ameter of vane blades, and $\mathrm{h}=$ height of vane blades.

\section{Basement Description Conventions}

\section{Core Forms}

Core description forms for igneous and metamorphic rocks are not the same as those used for sediments. Igneous rock representation on these sheets is compressed, each column describing one $1.5 \mathrm{-m}$ section. All shipboard hand-specimen and thin-section descriptions are presented for each section in the right-hand column.

All basalts are split by rock saw into archive and working halves. The working half is described and sampled on board. In a typical basalt description form (Fig. 6), the left box is a visual representation of the working half. Two closely spaced horizontal lines in this column indicate the location of styrofoam spacers taped between basalt pieces inside the liner. Each piece is numbered sequentially from the top of each section, beginning with the number 1 . Pieces are labeled on the rounded, not the sawed, surface. Pieces that could be fit together before splitting are given the same number, but are lettered consecutively, such as "1A, 1B, 1C." Spacers are placed between pieces with different numbers but not between those with different letters and the same number. In general, addition of spacers represents a drilling gap (no recovery). All pieces that are cylindrical and longer than the liner diameter have orientation arrows pointing up, on both the archive and working halves. Special procedures ensure that orientation is preserved through every step of the sawing and labeling process. All orientable pieces are indicated by upward-pointing arrows to the right of the graphic representation on the description forms. Because the pieces are rotated during drilling, it is not possible to sample for declination studies.

Samples were taken for various measurements on board. The type of measurements and approximate location are indicated in the "Shipboard Studies" column, by the following notation:

$\mathrm{M}=$ magnetism measurement

$\mathrm{S}=$ sonic-velocity measurement

$\mathrm{T}=$ thin section

$\mathrm{D}=$ density measurement

$\mathrm{P}=$ porosity measurement

The state of alteration (see Fig. 6 for symbols) is shown in the "Alteration" column.

\section{Igneous and Metamorphic Rock Classification}

Basalt was recovered on Leg 72. Classification is based mainly on mineralogy and texture. Basalts are termed aphyric, sparsely phyric, moderately phyric, or phyric, depending on the proportion of phenocrysts visible with the binocular microscope (about $\times 12$ ). Basalts are called aphyric if phenocrysts are absent. For practical purposes, this means that if one piece of basalt was found with a phenocryst or two in a section where all other pieces lack phenocrysts, and no other criteria, such as grain size or texture, distinguish this basalt from the others, then it too is described as aphyric. A note of the rare phenocrysts is included in the general description, however. This approach enables us to restrict the number of lithologic units to those with clearly distinctive and persistent visible differences.

Sparsely phyric basalts are those with $1-2 \%$ phenocrysts in almost every piece of a given core or section. Clearly contiguous pieces without phenocrysts are included in this category, and again the lack of phenocrysts is noted in the general description.

Moderately phyric basalts contain $2-10 \%$ phenocrysts. Aphyric basalts within a group of moderately phyric basalts are separately termed aphyric basalts.

Phyric basalts contain more than $10 \%$ phenocrysts. No separate designation is made for basalts with more than $20 \%$ phenocrysts; the proportion indicated in the core forms should be sufficient to guide the reader.

The basalts are further classified by phenocryst type, and a modifying term precedes such terms as phyric and sparsely phyric. A plagioclase-olivine, moderately phyric basalt contains $2-10 \%$ phenocrysts, most of them plagioclase but with some olivine. 


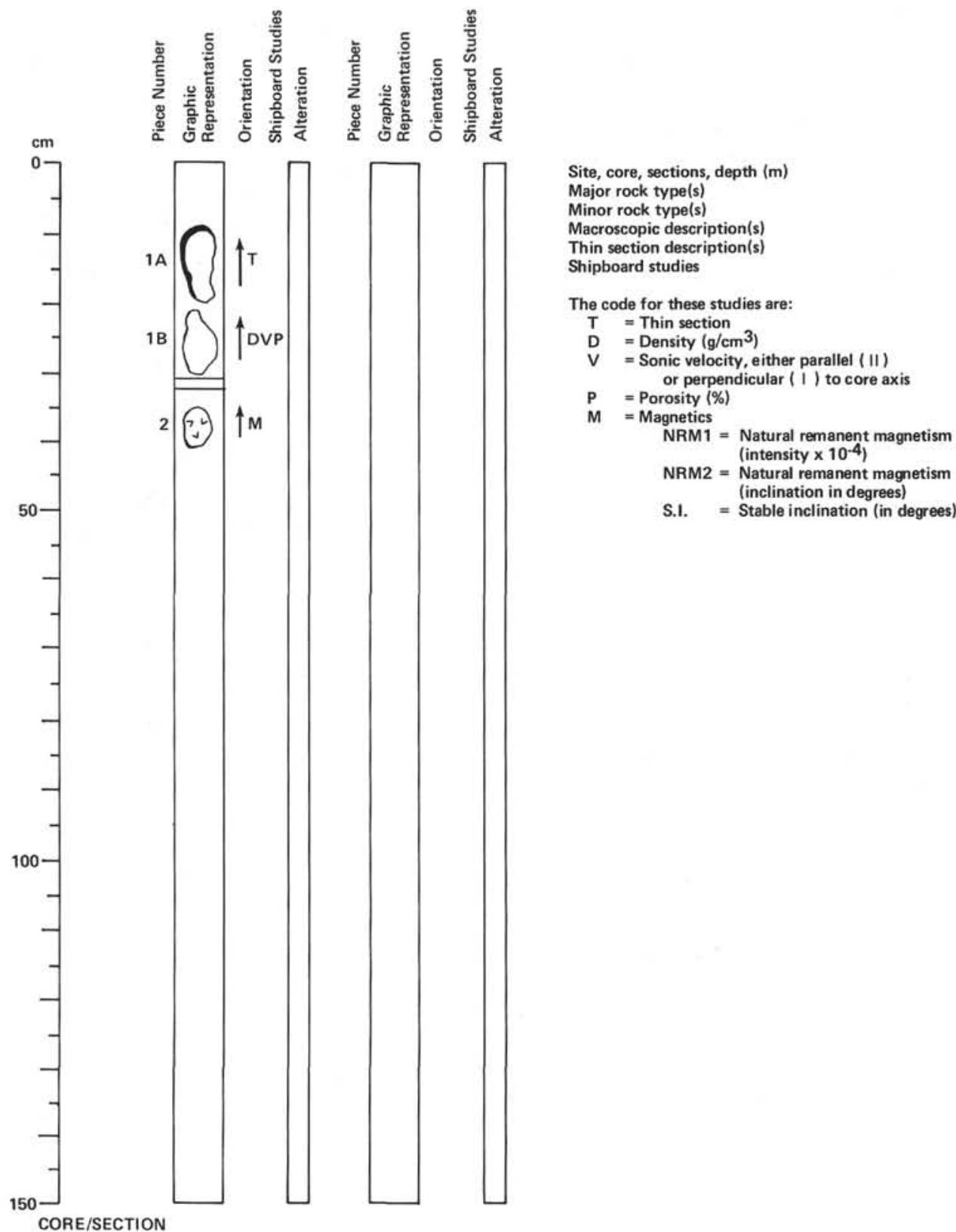

Figure 6. Visual core description form for igneous rocks.

\section{PHOTOGRAPHY}

Sets of color and black and white negatives of whole cores are available for consultation. In addition, negatives in black and white for close-up documentation of special structures are archived at DSDP.

\section{OBTAINING SAMPLES}

Potential investigators who desire to obtain samples should refer to the DSDP-NSF Sample Distribution Policy. Sample request forms may be obtained from the Curator, Deep Sea Drilling Project, A-031, University of California, San Diego, La Jolla, CA 92093. Requests must be as specific as possible; include site, core, section, interval within a section, and volume of sample required.
Requests for underway geophysical data should be sent to Manager, Data Group, Deep Sea Drilling Project, A-031, University of California, San Diego, La Jolla, CA 92093.

\section{REFERENCES}

Bennett, R. H., and Keller, G. H., 1973. Physical properties evaluation. In van Andel, T. H., Heath, G. R., et al., Init. Repts. DSDP, 16: Washington (U.S. Govt. Printing Office), 521-528.

Berggren, W. A., 1973. The Pliocene time scale: calibration of planktonic foraminiferal and calcareous nannoplankton zones. Nature, 243:391-397.

1977a. Late Neogene planktonic foraminiferal biostratigraphy of Site 357 (Rio Grande Rise). In Supko, P., Perch-Nielsen, K., et al., Init. Repts. DSDP, 39: Washington (U.S. Govt. Printing Office), 591-615.

1977b. Late Neogene planktonic foraminiferal biostratigraphy of the Rio Grande Rise (South Atlantic). Mar. Micropaleontol., 2:265-313. 
Blow, W. H., 1969. Late middle Eocene to Recent planktonic foraminiferal biostratigraphy. In Brönnimann, P., and Renz, H. H. (Eds.), Proc. First Int. Conf. Plankt. Microfossils: Leiden (E. J. Brill), 1:199-241.

Boyce, R. E., 1976. Definitions and laboratory techniques of compressional sound velocity parameters and wet-water content, wet-bulk density, and porosity parameters by gravimetric and gamma ray attenuation techniques. In Schlanger, S. O., Jackson, E. D., et al., Init. Repts. DSDP, 33: Washington (U.S. Govt. Printing Office), 931-958.

1977. Deep Sea Drilling Project procedures for shear strength measurements of clayey sediment using modified Wykeham Farrance Laboratory vane apparatus. In Barker, P. F., Dalziel, I. W. D., et al., Init. Repts. DSDP, 36: Washington (U.S. Govt. Printing Office), 1059-1068.

Gealy, E. L., Winterer, E. L., and Moberly, R. M., Jr., 1971. Methods, conventions, and general observations. In Winterer, E. L., Riedel, W. R., et al., Init. Repts. DSDP, 7, Pt. 1: Washington (U.S. Govt. Printing Office), 9-26.

Gieskes, J. M., and Rogers, W. C., 1973. Alkalinity determination in interstitial waters of marine sediments. J. Sediment. Petrol., 43: 272-277.

Gombos, A. M., Jr., and Ciesielski, P. F., 1983. Late Eocene to early Miocene diatoms from the southwest Atlantic Ocean. In Ludwig, W. J., Krasheninnikov, V. A., et al., Init. Repts. DSDP, 71: Washington (U.S. Govt. Printing Office), 583-634.

Matthews, D. J., 1939. Tables of the Velocity of Sound in Pore Water and in Seawater: London (Admiralty, Hydrographic Department).

Mitchell, J. K., 1976. Fundamentals of Soil Behavior: New York (John Wiley \& Sons, Inc.).

Müller, G. and Gastner, M., 1971. The "Karbonate-Bombe," a simple device for determination of the carbonate content in sediments, soils and other materials. Neues Jahrb. Mineral. Monatsh., 10: 466-469.
Munsell Soil Color Charts, 1971. Baltimore, MD (Munsell Color Company, Inc.).

Perch-Nielsen, K., 1977. Albian to Pleistocene calcareous nannofossils from the western South Atlantic, DSDP Leg 39. In Supko, P. R., Perch-Nielsen, K., et al., Init. Repts. DSDP, 39: Washington (U.S. Govt. Printing Office), 699-823.

Prell, W. L., Gardner, J. V., and Shipboard Scientific Party, 1982. Leg 68: introduction and explanatory notes, and conventions. In Prell, W. L., Gardner, J. V., et al., Init. Repts. DSDP, 68: Washington (U.S. Govt. Printing Office), 5-13.

Riedel, W. R., and Sanfilippo, A., 1971. Cenozoic radiolaria from the western tropical Pacific, Leg 7. In Winterer, E. L., Riedel, W. R., et al., Init. Repts. DSDP, 7, Pt. 2: Washington (U.S. Govt. Printing Office), 1529-1672.

1978. Stratigraphy and evolution of tropical Cenozoic radiolarians. Micropaleontology, 24:61-96.

Stainforth, R. M., Lamb, J. L., Luterbacher, H., Beard, J. H., and Jeffords, R. M., 1975. Cenozoic planktonic foraminiferal zonation and characteristics of index forms. Contrib. Univ. Kans., Article 62 .

Terzaghi, K., and Peck, R. B., 1967. Soil Mechanics in Engineering Practice (2nd ed.): New York (John Wiley and Sons, Inc.).

van Hinte, J. E., 1976. A Cretaceous time scale. Am. Assoc. Pet. Geol. Bull., 60:498-548.

Wentworth, C. K., 1922. A scale of grade and class terms of clastic sediments. J. Geol., 30:377-390.

Wentworth, C. K., and Williams, H., 1932. The classification and terminology of the pyroclastic rocks: report of the Committee on Sedimentation. Bull. Nat. Res. Counc. U.S., 80:10-53.

Date of Initial Receipt: October 29, 1982 